\title{
Engineered Gene
}

National Cancer Institute

\section{Source}

National Cancer Institute. Engineered Gene. NCI Thesaurus. Code C40985.

A gene that has been artificially altered in sequence or structure. 